\title{
Sitting with the Demons - Mindfulness, Suffering, and Existential Transformation
}

\author{
Sebastjan VÖRÖS*
}

\begin{abstract}
In the article, I critically evaluate some common objections against contemporary approaches to mindfulness meditation, with a special focus on two aspects. First, I consider the claim that de-contextualized contemporary approaches may have serious ethical consequences (the so-called problem of "mindful sniper/zombie"); second, I investigate the suggestion that it may be misleading to construe mindfulness meditation as (simply) a relaxation and/or attention-enhancing technique, as it is sometimes accompanied by unpleasant, even terrifying phenomena (the so-called "dark night of the soul"). In the last two sections, I weave the two narratives together by putting forward the following claim: traditionally-minded criticisms of contemporary approaches are ultimately correct, but for the wrong reasons - the historical context is not important in itself, but because of the role it plays in confronting the practitioner with the fundamental existential questions. In this sense, mindfulness meditation can be conceived as an important, but not the only element of a broader process of overcoming existential angst, whose ultimate goal is not relaxation or enhanced attention, but rather a radical existential transformation.
\end{abstract}

Keywords: Buddhism, mindfulness meditation, ethics, intercultural dialogue, suffering, Kabat-Zinn

\section{Izvleček}

Članek kritično pretrese nekaj pogostih ugovorov zoper sodobne pristope k čuječnostni meditaciji s posebnim poudarkom na dveh vidikih: prvič, obravnava kritike, ki pravijo, da bi dekontekstualizirani sodobni pristopi utegnili imeti resne etične posledice (t.i. problem »čuječega ostrostrelca/zombija«); in drugič, raziskuje ugovore, da bi bilo čuječnostno meditacijo problematično pojmiti (zgolj) kot tehniko za sproščanje ali izboljševanje pozornosti, saj jo občasno spremljajo neprijetni, celo zastrašujoči pojavi (t.i. »temna noč duše«). V zadnjih dveh razdelkih se oba vidika združita v trditvi: tradicionalni kritiki sodobnih pristopov imajo $v$ zadnji instanci prav, a iz napačnih razlogov - zgodovinski kontekst ni pomemben zaradi samega sebe, temveč zaradi vloge, ki jo igra, ko praktikanta sooča s temeljnimi bivanjskimi vprašanji. $V$ tem oziru bi lahko čuječnostno meditacijo označili za pomembno, a nikakor ne edino prvino širšega procesa preseganja eksistencialne

Sebastjan VÖRÖS, Assistant Professor, Department of Philosophy, Faculty of Arts, University of Ljubljana, Slovenia. sebastjan.voros[at]ff.uni-lj.si

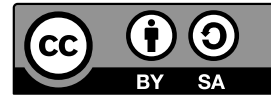


tesnobe, katerega glavni cilj ni sproščanje ali povečana pozornost, temveč korenita bivanjska preobrazba.

Ključne besede: budizem, čuječnostna meditacija, etika, medkulturni dialog, trpljenje, Kabat-Zinn

\section{Mindfulness in the West: in the Shadow of McMindfulness?}

In the past two decades, there has been an explosion of interest in mindfulness and mindfulness-based meditative techniques. The number of studies on the nature, dynamics, and effects of mindfulness meditation has thus been growing exponentially (from five in 1990, through 21 in 2000, up to 353 in 2010; Black 2014). For example, cognitive (neuro) science has been diligently mapping neurobiological changes in response to mindfulness meditation (Chiesa and Serretti 2010; Edwards et al. 2011; Tang et al. 2015), and has been toying with the possibility of integrating Buddhist meditative techniques into consciousness studies (Kordeš and Markič forthcoming; Thompson 2007; Vörös 2016). In medicine and psychotherapy, mindfulness-based interventions (MBIs) are used in the treatment of various psychophysical disorders (from chronic pain and hypertension to insomnia, depression, and anxiety disorders) (Chiesa and Malinowski 2011; Grossman et al. 2004; Sedlmeier et al. 2012). Finally, attempts have been made to introduce mindfulness meditation not only into educational and corrective facilities, but also into companies, government agencies, even military and police departments (Sauser and Kohls 2010; Stanley and Jha 2009). A corollary of these developments has been an increase of interest in certain other aspects of Buddhist philosophy (Garfield 2015; Siderits 2007): the idea of "non-self" (Pāli anatta; Skt. anātman) has found fertile terrain in the philosophy of mind, psychology, and cognitive science; the "idea of dependent origination" (Skt. pratìtyasamutpāda; Pāli paticcasamuppāda) has garnered attention in metaphysics, ecology, ethics, and other fields.

More recently, however, this surge in popularity has become a topic of heated debate in both the academic literature (see especially Contemporary Buddhism [12 (1), 2011] and Mindfulness [6 (1), 2015]) and the scientific/therapeutic "blogosphere" (e.g. Healey 2013; Purser and Loy 2013; Segall 2013). The main bone of contention seems to revolve around the question of whether, and to what extent, contemporary (mis)appropriations and (mis)applications of mindfulness meditation could be said to distort the age-old Buddhist practice. In addition to media

1 This paper partly draws and elaborates upon two of my previous papers on the topic (see Vörös 2015 and Vörös forthcoming). 
hype and overblown claims that frequently accompany mindfulness studies (Kerr 2014; Purser 2015a, 33), critics have been especially vocal about the dangers of the so-called "mystification of mindfulness" (Wilson 2014), a process in which mindfulness is extracted from its traditional religious and philosophical framework, and transformed into something more compatible with the Weltanschauung of the secular Western world. Throwing out such "traditional baggage" may have made modern versions of mindfulness more enticing to the average Westerner, but it has also given rise to a host of difficulties: In addition to conceptual ambiguities and methodological challenges (Chiesa and Malinowski 2011; Dorjee 2010), it has been suggested that contemporary appropriations substantially diverge from traditional definitions and practices (Gethin 2011; Olendzki 2011); that they make uncritical use of, and frequently misinterpret, central Buddhist concepts (Wallace 2012); that they ignore or trivialize other (particularly ethical) aspects of Buddhist practice (Hickey 2010; Purser 2015 a, b); and that they therefore run the risk of not only incorrigibly distorting the original practice, but also of exposing its practitioners to inadvertent harm (Dobkin et al. 2011). "McMindfulness" (Purser and Loy 2013), as these contemporary trends are sometimes derogatorily called, is said to have become a puppet in the hands of corporate capitalism: The revolutionary impetus of Buddha's teaching has been watered down and transformed into a yet another self-help method promulgating uncritical, docile and subservient attitudes among employees and upholders of the existing "law and order".

The present paper aims to critically evaluate these objections, with special focus on two aspects. First, it takes a closer look at the claims that contemporary approaches, in trying to extricate mindfulness from its traditional framework, give rise to serious ethical dilemmas (the so-called problem of "mindful sniper/zombie"). Second, it investigates the warnings that promoting mindfulness meditation as simply a relaxation and/or attention-inducing technique is misleading, as it neglects the fact that it is sometimes accompanied by unpleasant, even terrifying phenomena (the so-called "dark night of the soul"). Drawing on these two aspects, I then go on to argue that the most vocal critics are ultimately right, but for the wrong reasons - the historical context from which personal mindfulness-based practices have been extricated is not important in itself, but because of the role it plays in confronting the practitioner with fundamental existential questions. In this sense, mindfulness meditation can be construed an important, but by no means the only element of a broader process of overcoming existential angst, whose goal is not (only) calmness or (let alone) optimization of productivity, but rather a radical (and even tortuous) existential transformation. 


\section{Modern Samurais and Ninja Warriors: on the Popularization of Mindfulness}

Let us begin with a brief exposition of a historical narrative against which contemporary criticism is usually set, namely that of "Buddhist Modernism", sometimes also termed "Protestant Buddhism" (Lopez 2002; McMahan 2008; Sharf 1995, 2014a). The term designates new forms of Buddhism that are said to have emerged approximately 150 years ago in South-East and East Asia out of an engagement with Western modernity and a concomitant reaction against the "obscurantism" of older (i.e., more traditional) Buddhist traditions. The intellectual elites in the colonized or semi-colonized Asian countries, swayed by the popular Western political, social and intellectual currents (from nationalism and (neo)romanticism, through theosophy and modern forms of Christianity, to rationalism and modern science), set out to recover their own cultural, religious and philosophical heritage by purging it of all "inauthentic" ("superstitious", "dogmatic", "irrational", etc.) elements that might be distasteful to modern ("enlightened", "rational", etc.) sensibilities.

The reformatory zeal of Buddhist Modernism has found its expression in the work of many different thinkers and movements, but for our present purposes the most relevant among these is the so-called "Theravāda Revival" of South-East Asia. In their quest to recover national identity, many intellectuals from Sri Lanka, Laos, Thailand, and particularly Burma (Myanmar) have taken recourse to Theravāda Buddhism, seeing it as the traditional wellspring of their cultural and spiritual heritage. However, as is so common in history, the process of "recovery" of one's self-identity turned out to be equally, if not even more heavily, dependent on "construction" than on "re-construction", so the end result turned out to be quite different from the Buddhism of their forefathers. Heavily influenced by the ideals and values of Western modernity, these reformists are said to have refashioned Theravāda Buddhism in the image of Post-Enlightenment Christianity, with special emphasis on individualism (the primacy of personal liberation), rationalism (elimination of all "supernatural" and "magical" elements), universalism (liberation available to all, rejection of the authority of the clergy), and textualism (systematic study of scriptural legacy of Theravāda Buddhism) (Sharf 1995, 251-2).

These aspects have, in turn, created fertile grounds for the development of the "Vipassanā" or "Insight Meditation Movement", whose main goal was to (re)introduce meditation into the heart of the Buddhist path. As pointed out by Sharf, prior to the reformatory endeavours of meditation teachers such as Phra Acharn Mun (1870-1949) in Thailand, Anagārika Dharmapalā (1864-1933) in Sri Lanka, Migun Sayādaw (U Nārada; 1868-1955) and Ledi Sayādaw (1864-1923) in 
Burma, the mainstay of religious practice in Theravāda tradition wasn't meditation, but various devotional practices (chants, recitations, etc.) whose aim was the accumulation of merit and cultivation of wholesome attitudes (ibid., 242). The "Vipassanā Movement" sought to "revive" the old meditative tradition, and the method which proved most successful in this respect, was the (in)famous "New Burmese Method," developed by Migun Sayādaw, and later popularized by his most influential student Mahāsī Sayādaw (1904-1982) (Purser 2015a, 29-30; Sharf 2014a, 3-4). Mahāsī is said to have simplified the traditional Theravāda meditative practice-e.g., the meditator could immediately start cultivating "insight" (Pāli vipassanā), without having to first develop advanced skill in "concentration" (Pāli samatha), etc.- - and thus made it more accessible to laypersons. Even more importantly,

Mahāsī placed emphasis on the notion of sati, understood as the moment-to-moment, lucid, non-reactive, non-judgmental awareness of whatever appears to consciousness. One of Mahāsīs most influential students, the German born monk Nyanaponika Thera (Siegmund Feniger, 1901-1994), coined the term "bare attention" for this mental faculty, and this rubric took hold through his popular 1954 book The Heart of Meditation. (Sharf 2014a, 4).

Mahāsîs view of mindfulness meditation was later adopted by a group of American and European students, among them Jack Goldstein, Jack Kornfield, and Sharon Salzberg, who in 1975 founded the Insight Meditation Society (IMS). IMS has had tremendous impact on the reception and perception of Buddhism and mindfulness in the West (MacKenzie 2001). One of the members of IMS was Jon Kabat-Zinn, who in 1979 established the Stress Reduction Clinic, where he developed Mindfulness-Based Stress Reduction (MSBR), the first and probably still best-known MBI (Kabat-Zinn 2011, 286). The influence of the Mahāsī-Nyanaponika tradition on MBSR can be seen in Kabat-Zinn's classical definition of mindfulness as "paying attention in a particular way; on purpose, in the present moment, and non-judgmentally" (ibid. 2014, 4).

From here on, we are faced with a familiar story: mindfulness, construed as "a kind of nonelaborative, non-judgmental, present-centered awareness in which each thought, feeling or sensation that arises in the attentional field is acknowledged and accepted as it is" (Bishop et al. 2004, 232), soon became an integral part of several other $\mathrm{MBIs}^{2}$, and has gradually started seeping into Western societies

2 In addition to MSBR, the three arguably most famous MBIs would be Mindfulness-Based Cognitive Therapy (MBCT), Dialectical Behavior Therapy (DBT), and Acceptance and Commitment Therapy (ACT) (see Chiesa and Malinowski 2011). 
at large. In addition to its original (i.e., therapeutic) setting, attempts have been made to incorporate it into educational and corrective facilities, companies, andthe point that critics find particularly worrisome - the army and police. For example, drawing inspiration from Kabat-Zinn's MSBR, Elisabeth Stanley developed what is now called Mindfulness-Based Fitness Training (MMFT or M-Fit), an eight-week meditation course that is taught to soldiers prior to their deployment in order to equip them with "mental armour" against emotional and cognitive breakdown (Purser 2014). Similarly, more and more traders, managers, and the like now turn to mindfulness meditation in order to "fine-tune their brains" and "up their game", sometimes referring to themselves as the "new samurais" or "ninja warriors" (Burton and Effinger in Purser 2015a, 41). As suggested in the previous section, these recent developments triggered what Segall (2013) terms a "Thermidorian reaction", whose two aspects - the neglect of a broader (particularly ethical) framework and challenging psycho-physical phenomena-will be the topics of the next two sections, respectively. Before proceeding to these matters, however, two brief comments are in order.

First, Purser (2015a, 29-30), himself a fierce critic of contemporary approaches to mindfulness, points out several historical inaccuracies in the classical account of the genesis of Vipassanā Movement. Not only have both Migun and Mahāsī Sayādaw incorporated rituals (chanting, invocations, etc.) into their meditation courses, but it also erroneous to accuse them of having made up the "bare insight" method, as the latter can already be found "in the Visuddbimagga and the Pāli commentaries" (ibid., 30). Moreover, Ledi and Mahāsī, who were both well-versed in classical Pāli texts, insisted that meditative practice needs firm textual grounding; thus, according to Mahāsi, the bare awareness of the present constitutes only the beginning of meditative practice, which later follows the classical stages of insight as laid out in the Pāli cannon. Secondly, and in opposition to the claims put forward by some of his contemporary critics, Kabat-Zinn did not base his interpretation of mindfulness exclusively on the "New Burmese Method", but was also greatly influenced by Mahāyāna Buddhism, particularly Zen, as well as certain Yogic traditions and the teachings of J. Krishnamurti and Ramana Maharshi (Kabat-Zinn 2011,289). Claiming that he distorted and/or diluted the historical Buddhist method is thus problematic, as it was clear that what he sought was not a faithful replica, but an effective amalgam (more on this in the last section). All this goes to show that there are several lacunae in the "Buddhist Modernism" hypothesis, which should therefore be taken cum grano salis. 


\section{Of Mindful Snipers and Zombies: Mindfulness and Ethics}

We can now move on to the discussion about the relationship between mindfulness and ethics, which I will present here in the form of a series of back-andforth exchanges, pro et contra. To begin with, it is claimed by the more traditionally-minded critics that, in order to be able to attain the appropriate understanding of mindfulness, one must take into account the broader context in which it had emerged (Monteiro et al. 2015, 2-3). This context is said to be largely determined by the Four Noble Truths (Pāli cattāri ariyasaccāni): (1) human existence is characterized by suffering or unpleasantness (Pâli $d u k k h a$ ); (2) the origin of suffering is craving or desire (Pāli tanh $\bar{a})$; (3) the cessation of suffering is attainable through the cessation of craving; (4) the way to cessation of suffering is the Noble Eightfold Path, consisting of wisdom (Pāli pañ ña) (right view, right intention), ethics (Pāli sìla) (right speech, right action, right livelihood), and concentration (Pāli samādhi) (right effort, right concentration, right mindfulness). Two things are of particular interest here. First, mindfulness (Pāli sati; Skt. smṛti) is only one aspect of the Noble Eightfold Path. Second, just like the other seven aspects, it is qualified by the adjective "samm $\vec{a}$ ", which is normally translated as "right" (the opposite of "wrong"), but actually carries a wide range of meanings: "attuned", "balanced", "complete", "perfect", "wholesome", etc. (Amaro 2015, 64; Mikulas 2015, 15; Olendzki 2011, 64).

In addition to samma sati or right (attuned, etc.) mindfulness there can then also be micchà sati or wrong (not attuned, etc.) mindfulness, i.e., mindfulness which does not alleviate suffering, but actually exacerbates it (Stanley 2015, 103). But, as pointed out by Sharf, there seems to be very little that is "bare" or "non-judgmental" in traditional accounts of sammā sati (Sharf 2014a, 943). First off, the notion of mindfulness in Theravāda Buddhism preserves links to the original meaning of the term sati, which is "memory" or "remembering" (but see Bodhi 2011 for a more nuanced account). This is true in two senses: In the narrow sense, mindfulness is associated with working memory, and refers to the ability of the mind to attend closely to a given object and prevent it from drifting away to some other object (Dreyfus 2011, 51); in the broad sense, the ties with memory are even more explicit, and the term refers to the capacity to "recollect one's larger sense of purpose, one's spiritual goals, and especially, the ethical framework within which practice occurs" (Harrington and Dunne forthcoming, 18). However, the story does not end here. Sati in Theravāda Buddhism is described not only as retentive and recollective (and therefore different from present-centered awareness), but also as explicitly evaluative (Dreyfus 2011, 51): it recognizes wholesome mental states as wholesome and unwholesome mental states as unwholesome, embracing the former 
and shunning the latter (Gethin 1992, 39). There is, in other words, an etbical element inherent in the classical account of mindfulness; and this element, as we have seen, is firmly embedded into the traditional framework of the Four Noble Truths and the Noble Eightfold Path, which provide it with direction, meaning, and purpose.

To this, the contemporary advocate may reply that, throughout history, Buddhist doctrine and practice have undergone numerous transformations, continually adapting themselves to specific social and cultural circumstances. Thus, to insist that it is necessary to preserve the original framework smacks of doctrinal purism that is blind to the ever-changing nature of things, and thus actually inimical to the spirit of Buddhism. Further, it is emphasized that, all too often, "traditionalists" fail to distinguish between implicit and explicit ethics: although it might be true that contemporary approaches pay significantly less attention to the explicit ethical teachings, one might argue that there is greater appreciation of implicit ethical values as embodied in the person of the meditation teacher. And since ethics in Buddhism is not so much about the fulfilment of duties, as it is about the full-blooded enactment of ethical virtues, contemporary approaches can actually be said to be closer to authentic Buddhist practice. Moreover, "traditionalist" critics seem to overlook the fact that contemplative practices similar to mindfulness meditation also appear in other religious traditions, so Buddhism cannot lay claim to "exclusive ownership". Moreover, since these other practices, albeit developed in very different contexts, seem to have similar, if not identical psychophysical effects, it is simply wrong to maintain that the Buddhist context is indispensable for them (McCown 2013; Monteiro et al. 2015, 6-7; Purser 2015a, 36-7).

However, the critic might retort that, if mindfulness is isolated from its overall, particularly ethical, context, as is the case with contemporary approaches, it risks becoming seriously distorted. This holds especially true if it is transmitted into contexts that seem to be not only incongruent with, but actually antithetical to, traditional Buddhist ethics, such as the corporate world, military, and police. Here, the threat of misuse and misappropriation seems most acute, as is vividly depicted by the metaphors of "mindful sniper" and "mindful zombie". A mindful sniper is someone who has acquired great proficiency in cultivating "bare attention", but uses this capacity for purposes that are in blatant disagreement with Buddhist ethical standards, i.e., to optimize their military skills (Ricard 2009). A mindful zombie, on the other hand, is a "corporative complement" to the mindful sniper, and stands for someone who, passively and non-judgmentally, accepts the rapaciousness of the corporate world. In these contexts, mindfulness becomes an efficient means for cultivating a set of skills (improved concentration, productivity, stress-resilience, etc.) deemed valuable by the predominant political and/ 
or economic forces (Purser 2015a, 39-40). Wilson refers to this as "laissez-fare mindfulness" (Wilson 2014, 194), which, under the banner of "ethical neutrality", uncritically embraces values promulgated by the free-market economy (individuality, competitiveness, unbridled productivity, etc.).

In reply, the proponents of contemporary approaches can offer (at least) two counterarguments. First, an individualized approach to spiritual practice is not a contemporary gimmick, but an integral part of the Buddhist tradition. For instance, the Mahāyāna notion of "skillful" or "expedient means" (Skt. upāya) emphasizes the importance of adjusting spiritual practice to the individual practitioner. As such, a given set of views and/or techniques may prove expedient for a given practitioner, even if, from the perspective of a Buddha (i.e., someone who has become awakened), it may not be ultimately true (Monteiro et al. 2015, 6-7). A skillful teacher will always pay close attention to the circumstances in which the individual practitioner finds herself and use them to her benefit. If, for instance, the practitioner happens to be an entrepreneur, soldier or police officer, the teacher will try to introduce her to mindfulness meditation within the context of her specific profession. In fact, it would be contrary to the Buddhist values of generosity and compassion to deny anyone (be it a police officer, soldier or entrepreneur) the opportunity of getting acquainted with Buddhist teachings and practice (Van Gordon et al. 2015, 53). Second, mindfulness meditation might make a sharpshooter more focused and less distracted, which, in turn, might result in fewer civilian casualties. Moreover, it may make the sharpshooter more keenly aware of the existential gravity of her actions, which might cause her to reduce the killings to the bare minimum, or even to resign from the army (Mikulas 2015, 16). In the last analysis, the main goal of contemporary approaches seems to be quite similar, if not identical, to that of classical approaches, namely finding creative ways to efficiently alleviate suffering. In this respect, the "rhetoric of authenticity" (Dreyfus 2011, 42; Dunne 2015, 252) may actually prove disruptive for collaborative efforts, and may turn out to be a hindrance in achieving this overarching, common goal (Monteiro et al. 2015, 10-12; Davis 2015, 47-8).

However, if we now look at the last swing of this dialectic pendulum, critics are likely to express doubt as to such "transhistorical levelings", emphasizing that, while the notion of "skillful means" can, indeed, be found in certain Buddhist traditions, it is (even in Mahāyāna) limited to Buddhas and Bodhisattvas - and it is far from certain whether someone who has received a certificate to teach meditation after a six- or eight-week training course would fall into that category (Purser 2015a, 37). Moreover, Theravāda tradition finds the Mahāyāna concept of upaya problematic for several reasons, not least because it can be readily misused to provide doctrinal support for unbridled violence (ibid., 39). Victoria (2006) 
and Sharf (1993) have, for instance, shown how Mahāyāna teachings have been (mis)appropriated in the past by the Japanese government to support its aggressive nationalist politics. Second, while it may be true that both contemporary and traditional approaches aim at "reducing suffering", the traditional Buddhist conception of "suffering" tends to be much broader than the one put forward by most contemporary MBIs. For instance, Purser maintains that it is possible to distinguish three "forms" or "levels" of suffering in traditional Buddhist accounts: (a) the suffering of suffering (Pāli dukkha-dukkha): a "gross level of suffering" pertaining to the unpleasantness of birth, illness, old age, and dying, and to anxiety, depression, and pain that usually accompany these ineliminable aspects of human existence; (b) the suffering of change (Pāli viparinama-dukkha): a "second-level" suffering related to the realization of the transitory and impermanent nature of all phenomena; and (c) the suffering of conditioned existence or all-pervasive suffering (Pāli sankhara-dukkha): a "third-level" of suffering, characterized by "deep existential suffering, or angst", a "sense of lack" or a "primal fear that [one's] self may be groundless, empty, and devoid of permanent and separate identity" (Purser 2015b, 680-1). From the Theravāda perspective, contemporary MBIs recognize and address only the first form of suffering, whereas they are largely ignorant of the remaining two forms. However, in order to prevent, and ultimately subdue, the pangs of existential fire, it will not do to simply extinguish the flames (a); one also needs to remove the embers (b) and the tinder (c). In other words, MBIs may provide for an epistemological shift, but not for an ontological one-they can engender changes in behaviour based on a more appreciative and aesthetically open stance towards one's ordinary experience, but they do not lead to a radical transformation in one's mode of being, because there is "no radical questioning of the nature of what we hold to be true" (ibid., 681). The practitioner thus remains the "prisoner of her own self", which can, in the long run, even exacerbate her suffering, as she becomes confronted with the (subconscious, etc.) material that has previously remained hidden, and has no means to successfully cope with it.

\section{The Dark Night of the Soul: Mindfulness and Suffering}

Reflections on the forms or levels of suffering bring us to our next topic, the question of whether mindfulness meditation can be "dangerous". It has recently been suggested (Dobkin et al. 2011; Rocha 2014) that the common conception of mindfulness meditation as a harmless relaxation and/or attention-enhancing technique might be problematic, as it can sometimes be accompanied by unpleasant psychophysical phenomena. What is striking in contemporary discussions, however, is that this topic hardly ever gets mentioned-despite the fact that 
traditional meditation manuals and the spiritual biographies of meditation experts often contain very elaborate accounts of such painful and frightening experiences. In Theravāda Buddhism, for instance, the meditator is said to go through seven stages of purification (Pāli satta-visuddhi), some of which are described in very unpleasant terms. During the sixth stage ("purification by knowledge and vision of the way;" Pāli patipada-ñanadassana-visuddhi) the practitioner has to acquire nine "knowledges." Upon acquiring the third knowledge ${ }^{3,4}$ - "awareness of fearfulness" ("knowledge of appearance of as terror"; Pāli bhayatupatthana-ñana) — the meditator realizes that all phenomena are continually "breaking apart" (dissolving), and is thus "gripped by fear and seems helpless" (Sayādaw 1995, 16). Upon acquiring the fourth knowledge - "knowledge of misery" ("knowledge of danger"; Pāli adinavanupassana-ñana) —all phenomena seem "insipid, without a vitalizing factor, and unsatisfying"; the meditator sees "only suffering, only unsatisfactoriness, only misery" (ibid.). Upon acquiring the fifth knowledge- "knowledge of disgust" ("knowledge of dispassion"; Pāli nibbidanupassana-ñana) - the meditator "finds no delight in those miserable things but is entirely disgusted with them"; at times, his mind becomes "discontented and listless [...] [e]ven if he directs his thought to the happiest sort of life and existence [...] his mind will not take delight in them" (ibid.,16). And upon acquiring the sixth knowledge- "knowledge of desire for deliverance" (Pāli muncitukamyata-ñana) — the meditator experiences "painful feelings" in the body, coupled with "an unwillingness to remain long in one particular bodily posture"; his only wish is to forsake all these dissolving formations and escape from them (ibid.).

Similarly, in his short practical manual on vipassana meditation, the already mentioned Mahāsi Sayādaw warns the reader that, during the training period, one may experience "unwholesome or frightening visions" (Sayādaw 1971, 1). In the initial stages, one may

experience sensations of intense pain: stifling and choking sensations, such as pain from the slash of a knife, the thrust of a sharp-pointed instrument, unpleasant sensations of being pricked by sharp needles, or of small insects crawling over the body [... but also] sensations of itching, biting, intense cold (ibid., 7);

3 I intentionally start with the third knowledge and omit the mention of the first two (i.e., "knowledge of contemplation of rise and fall" [Pāli udayabbayanupassana-ñana] and "knowledge of contemplation of dissolution" [Pāli bhanganupassana-ñana]), as they are irrelevant for our present purposes.

4 Note that, for convenience's sake, I'm using Mahāsī Sayādaw's (1995) much more comprehensive descriptions of individual stages, which, however, follow the general account in The Path of Purification (see Buddhaghosa 2011, 673-9). 
in later stages, the meditator

sometimes sees images of all kinds as if seeing them with his own eyes; for example, the Buddha comes into the scene in glorious radiance; a procession of monks in the sky; pagodas and images of the Buddha; meeting with beloved ones; trees or woods, hills or mountains, gardens, buildings; finding oneself face to face with bloated dead bodies or skeletons; swelling of one's body, covered with blood, falling into pieces and reduced to a mere skeleton; seeing in one's body the entrails and vital organs and even germs; seeing the denizens of the hells and heavens. (ibid., 20)

Similar reports can be found in other Buddhist traditions. In Japanese Zen, for instance, such unpleasant phenomena are called makyō (literally, "devil's cave"). A telling example are Hakuin's (1686-1768) well-known descriptions of "meditation" or "Zen sickness" - "an incurable disorder of the heart" — which plagued him on several occasions during his spiritual journey:

Before the month was out, my heart fire began to rise upwards against the natural course, parching my lungs of their essential fluids. My feet and legs were always ice-cold: they felt as though they were immersed in tubs of snow. There was a constant buzzing in my ears, as if I were walking beside a raging mountain torrent. I became abnormally weak and timid, shrinking and fearful in whatever I did. I felt totally drained, physically and mentally exhausted. Strange visions appeared to me during waking and sleeping hours alike. My armpits were always wet with perspiration. My eyes watered constantly. I traveled far and wide, visiting wise Zen teachers, seeking out noted physicians. But none of the remedies they offered brought any relief. (Hakuin 2010, 76)

Even more interestingly, similar accounts can be found not only in Buddhism, but also in other contemplative traditions, such as Christian mysticism. In fact, the phrase "dark night of the soul" was originally coined by the Spanish Christian mystic St. John of the Cross (1542-1591), who characterized it as the most "obscure and dark and terrible purgation" (John of the Cross 1946, 75), identical to "a living death of the Cross, both as to sense and as to spirit - that is, both inwardly and outwardly" (ibid., 140). Similarly, to name one last example, in an anonymous contemplative manual from the fourteenth century called The Cloud of Unknowing we read that, during later stages of contemplative prayer, "[w] ondefully is a man's affection varied in ghostly feeling": 
For at the first time that a soul looketh thereupon, it shall find all the special deeds of sin that ever he did since he was born, bodily or ghostly [...] Sometime in this travail him think that it is to look thereupon as on hell; for him think that he despaireth to win to perfection of ghostly rest out of that pain. Thus far inwards come many, but for greatness of pain that they feel and for lacking of comfort, they go back in beholding of bodily things [...]. (The Cloud 1922, 112)

Despite these and countless other accounts in traditional contemplative manuals, very few studies have been published on the unpleasant phenomena encountered during or after meditative practice, and even these centre mostly on clinical cases (Castillo 1990; Epstein and Lieff 1981; Kuijpers et al. 2007; Manocha 2000; Shapiro 1992). To my knowledge, only two (meta)studies (Dobkin et al. 2011; Lustyk et al. 2009) have been published so far that deal with the potential "side effects" or "contraindications" of MBIs, but even here most of the data is derived from the clinical studies mentioned above. In general, the following "complications" have been reported: anxiety and affective disorders, confusion and disorientation, depersonalization and derealization, depression, pain, insomnia and appetite loss, even short-term psychotic episodes. Both Dobkin et al. (2011) and Lustyk et al. (2009) point out that most reports contain little or no information on the nature and intensity of the meditative technique used, context in which it was performed, or the medical history of the practitioner. Further, the results of different studies sometimes conflict with each other: for example, while some studies imply that meditation can contribute to the onset of depersonalization (Castillo 1990; Shapiro 1992) and psychosis (Kuijpers et al. 2007; Manocha 2000), others suggest that it might be helpful in alleviating both conditions (see Chadwick et al. 2005 for psychosis, and Michal et al. 2007 for depersonalization). However, researchers agree that such phenomena merit further study, preferably with the aim of developing screening methods that would help to identify people who are more susceptible to such complications, and effecting intervention strategies that would enable more productive coping mechanisms.

The first steps in this direction were taken by Willoughby Britton, an assistant professor of psychiatry and human behaviour at Brown University and founder of the project called "Dark Night", later renamed "The Varieties of Contemplative Experience", whose aim is to systematically collect, analyze, and publicize reports on "challenging, difficult, or impairing" experiences (Cheetah House) that might occur during or after meditation practice. Relatedly, Prof. Britton runs the socalled "Cheetah House", a kind of "safe house" for people who have had any type of unpleasant experience with meditation. For example, David, "a polite, articulate 
27-year old" came to the Cheetah House in 2013, having experienced a (semi) psychotic breakdown during a prolonged meditative retreat. Several days into the retreat, he was flooded by "increasingly vivid pornographic fantasies and repressed memories from childhood": "I just started freaking out $[\ldots]$ and at some point, I just surrendered to the onslaught of unwanted sexual thoughts." He has developed frightful paranoid thoughts telling him to kill himself, coupled with visions of "death with a scythe and a hood" (Rocha 2014). Unfortunately, except for a handful of interviews and conference presentations, Britton has not yet published her research in any peer-reviewed academic journal. From a methodological and organizational perspective, the project seems very promising, since it includes not only psychiatrists and neuroscientists, but also teachers of mindfulness meditation from both traditional and contemporary perspectives (among them, one finds the pioneers of the "mindfulness movement", such as Kornfield and Goldstein). It is important to note, however, that Britton does not see her work as discrediting mindfulness meditation and/or MBIs - after all, she has not only been a longterm practitioner herself, but is also a licensed MBSR therapist. Instead, she sees it as an opportunity to obtain a more accurate picture of the studied phenomena. She is particularly interested in getting a better understanding of whether it is possible to distinguish between challenging experiences that are constitutive of the contemplative path from those that could be labelled as anomalous (i.e., pathological).

\section{Mindfulness Re- or De-contextualized?}

In these last two sections, I will try to weave the two narratives together by putting forward the following claim: that traditionally-minded critiques of contemporary mindfulness approaches are ultimately correct, but for the wrong reasons. I will start with the second (i.e., negative) part of the claim. To get a sense as to why critics might be wrong when they dismiss contemporary approaches as ahistorical aberrations, it is important to remember that "the Buddhist tradition is not monolithic" but "exhibits great diversity" (Dunne 2011, 71-72), and that there is therefore "no single authoritative Buddhist account of mindfulness" (ibid. 2015, 252). In other words, although it might be true that there are important differences between contemporary approaches to mindfulness and certain strands of Buddhism (notably, those related to the Theravāda Buddhism), this does not mean that there are no alternative conceptions of mindfulness within Buddhism (notably, those developed in Northern and East Asian Buddhism), which may align more closely with contemporary approaches. 
Dunne exemplifies this point by arranging Buddhist traditions along what might be called an innateist/constructivist spectrum (Dunne 2011, 75-79). The proposed classificatory criterion concerns the following question: "[W] hat is the continuity between an ordinary mind and the mind of a Buddha? [T]o what extent are the qualities of buddhahood or awakening (bodhi) present in an ordinary person?" (ibid., 75)

On the one end of the spectrum, we find constructivists who maintain that very few qualities of awakening are present, and that progress along the Buddhist path entails "eliminating obstructions" and "carefully acquiring or constructing appropriate qualities that eventually result in buddhahood". On the other end of the spectrum, we find innateists who argue that most or even all qualities of awakening are present, and that progress along the path requires "eliminating the obscurations that prevent our innate buddhahood from emerging" (ibid., 75-76; emphases added). According to this classification, Theravāda Buddhism, along with its classical conception of mindfulness, falls squarely in the constructivist camp; but there are other approaches-found particularly, but not exclusively, in the Mahāmudrā and Dzogchen traditions of Tibet, as well as in Chinese Chan, Japanese Zen and Korean Seon (Dunne 2015, 259; Sharf 2014b, 944)—that diverge significantly from the Theravāda views.

Both innateist and constructivist approaches start off from the general framework of the Four Noble Truths, as described in the first section, but disagree on the origin of "craving" or "desire" (Skt. trṣnāa), i.e., on the root cause of suffering (the Second Noble Truth). For constructivists, craving ultimately stems from distorted cognitions. The main goal of the Buddhist path (the Fourth Noble Truth) is thus to eradicate distorted cognitions (e.g., our belief in the permanence of things or the existence of the autonomous self) and replace them with wholesome qualities and capacities (e.g., compassion, clear comprehension) (Dunne 2015, 255). For innateists, on the other hand, the root of suffering lies deeper and has to do with the fundamental distinction between subject and object, i.e., with the notion of "a distinct subjectivity standing over against distinct objects of experience" (ibid., 259). It is this duality of knowing subject vs. known object (Skt. grähyagrāhakadvaya) that is said to be the ultimate source of distorted cognitions and consequently of craving and suffering in general. Cessation of suffering cannot be attained by the (progressive) eradication of unwholesome mental states and cultivation of wholesome ones, but by the (sudden) realization of the state of non-dual wisdom (Skt. advayajĩana) which is continually (if dimly) present in our everyday experience in the form of reflexive awareness (Skt. svasamvitti) (Dunne 2011, 73; Dunne 2015, 261). Unlike the classical "constructivist" accounts, where all conscious states, including all liberative meditative states, necessarily have a subject-object 
structure, the "innateist" approaches tend to emphasize the importance of states that precede, and thus transcend, the dual mode of experiencing.

It is for this reason that Maitripa (eleventh century), one of the most important proponents of Mahāmudrā tradition in Indian Buddhism, argues that what needs to be cultivated in meditation is not mindfulness (Skt. smrti) and attention (Skt. manasikära), but rather non-mindfulness (Skt. asmrti) and non-attention (Skt. amanasikāra) (Dunne 2011,77). As such, if according to the classical ("constructivist") Theravāda account, mindfulness comprises evaluative, judgmental and recollective aspects, then according to the non-dualist ("innateist") account, these aspects stay rooted in the subject-object duality and are therefore constitutive of ignorance (Skt. avidyā) (ibid. 2015, 262-3). Put differently, according to Mahāmudrā, cultivating mindfulness (in the classical sense of the term) strengthens subject-object structure and exacerbates suffering (ibid. 2011, 77). Consequently, the practical instructions provided by the adept Karmapa Wanchûg Dorjé (sixteenth century) sound remarkably similar to those found in contemporary approaches: "Do not pursue the past. Do not usher in the future. Rest evenly without present awareness, clear and nonconceptual." (ibid., 80) The meditator is asked to cultivate present-centered awareness, not allowing herself to get caught up in thoughts about the past or future, and to stop all conceptualizations, be it of the past, present or future, and simply rest in the state of clear awareness (ibid., 81).

Similarly, the most radically innateist currents in the early Chan movement argued that, instead of "maintaining mind", "discerning mind" and "mindfulness", as suggested by the more "moderate" (i.e., "constructivist-friendly") Chan advocates, one should cultivate "no mind" (Chin. wuxin), "cutting off discernment"(Chin.jueguan), and even, in a manner reminiscent of the Mahāmudrā tradition, "absence" (Chin. wusuo) and "no mindfulness" (!) (Chin. wunian) (Sharf 2014b, 945, 951). In other words, one should break completely with the constructivist tendencies of classical approaches. For instance, in the Treatise on No Mind (Chin. Wuxin lun) we read:

There is no mind. [...] You must simply observe intently and carefully: [...] Is this in fact the mind or not? Is it inside or outside, or somewhere in between? As long as one looks for the mind in any of these three locations, one's search will end in failure. Indeed, searching for it anywhere will end in failure. That's exactly what is known as "no mind". (ibid., 946)

And in reply to a query as to how one should practice no-mind, we find the following admonition: "Simply be wakeful with respect to all phenomena. 'No mind' itself is practice. There is no practice. Thus know that no mind is everything, and quiescent extinction is itself no mind.” (ibid., 947) 
So, where does this leave us? It would seem that, although diverging substantially from the ("constructivist") Theravāda account, contemporary approaches have close affinities to non-dualist ("innateist") views on mindfulness as propounded in certain Northern and East-Asian traditions. And if we are willing to cede "authenticity" to the latter, as we should, there is no reason to deny it to the former (Dunne 2015, 253). The most radical accusations of the "traditionalist" camp thus seem to rest on shaky grounds. But does this mean that their criticism is completely off the mark? Far from it. Note that, in addition to the nature and dynamics of the formal meditation practice, we must also consider the nature and dynamics of the informal or "in-between" practice, i.e., general guidelines on how to live (think, act, etc.) in the period between two formal sessions, so as to establish an environment conducive to the aims and objectives of contemplative practice (Dunne 2015; Kirmayer 2015). And here we do find telling differences between contemporary and traditional innateist approaches.

For example, a practitioner who wants to engage in formal Mahāmudrā practice is first required to undergo intensive training in "preliminary practices", which are then also rehearsed at the beginning of every meditation session. The main purpose of these practices is to instill "an intense concern for the suffering of [oneself and] others and a strong motivation to become capable of relieving that suffering" (Dunne 2015, 166). Also, as a part of the overall Mahāmudrā tradition, the practitioner is required to adopt "a paradigm of the proper Buddhist life along with its ethical norms" (ibid.). Although this paradigm, in contradistinction to the Theravāda tradition, is set aside during formal practice, this is only because it is believed that between formal sessions the specific nature of meditative practice will facilitate the fruition of goals and values that are central to a wholesome Buddhist lifestyle. There thus exists a delicate balance between formal and informal aspects of the practice: even the most "iconoclastic" among the traditional innateist approaches, i.e., approaches that eschew all conceptuality and normativity in formal practice, are embedded in a specific framerwork that provides the whole endeavour, at least initially, with purpose, orientation, and meaning. Put simply, even if we claim that, in the end, language (conceptual structures, judgments, beliefs, etc.) has to be discarded or transcended, we need to account for this fact in and through language. In other words, even if the goal of our practice is radical de-construction, one needs first to construct a meaningful narrative that will re-construct our previous beliefs and opinions so that we may reorient ourselves and start working towards the newly set goal.

What is thus often lacking in discussions about the (in)appropriateness of contemporary approaches to mindfulness is a more nuanced take on what is actually meant by "context". On the one hand, "context" can refer to the recollective, 
evaluative, and so on aspects that are said to (not) be integral to the formal practice ("narrow context"). On the other hand, it can denote a broader framework of values, purposes, and meanings into which such formal meditation practices are embedded ("broad context"). Take, for instance, Kabat-Zinn's MBSR. In his wish to produce a program that would "embody to whatever degree possible the dharma essence of the Buddha's teachings put into action", and make it accessible "to mainstream Americans facing stress, pain, and illness", without being peremptorily dismissed “as Buddhist, 'New Age', 'Eastern Mysticism' or just plain 'flakey', he probably did the right thing to opt for the more 'innateist' approach to Buddhist meditation" (Kabat-Zinn 2011, 282). In the scientistic climate of the 1970's and 1980's, all attempts to incorporate Buddhist meditation, in its traditional form, into the medical establishment were doomed to failure. In order to make it more palatable to the mainstream scientific and therapeutic communities of the period, it had to be presented in a form that could be integrated into the post-Enlightenment, secularized, multicultural and multiconfessional Western societies of the late twentieth century: mindfulness meditation, construed in "minimalist" terms as "bare attention", seemed more than fit for the task in this context.

On the other hand, it could be argued that the mechanisms and implications of such re-framing were inadequately reflected. For example, when Kabat-Zinn states that the aim of his work was simply to "share the essence of meditation and yoga practices", and that the "American vocabulary" he used for this particular purpose "spoke to the heart of the matter, and didn't focus on the cultural aspects of the traditions out of which the dharma emerged" (ibid., 287; emphases added), he gives the impression that contemporary conceptions of mindfulness constitute the neutral and universal essence of Buddhist meditation. Although it could be argued that this is not what Kabat-Zinn had in mind (at least not in such a crude and unqualified sense), as he explicitly points out that he never meant to

exploit, fragment, or decontextualize the dharma, but rather to recontextualize [!] it within the frameworks of science, medicine [...], and healthcare so that it would be maximally useful to people who could not hear it or enter it through the more traditional dharma gates (ibid., 288; emphasis in the original).

However, Kabat-Zinn's vague (and often contradictory) statements undoubtedly contributed to the rapid spread of such naive views. 


\section{Sitting with the Demons: Mindfulness and Existential Transformation}

We have now come to the crux of the matter: what is problematic in contemporary approaches is not their "innateist" understanding and practice of mindfulness meditation (narrow context), but rather their (implicit or explicit) belief that this form of practice constitutes the transhistorical "essence" of Buddhism, and that therefore other elements (broad context) can, and indeed should, be ignored. Since absolute decontextualization is an illusion and often simply masks (implicit, tentative) recontextualization, critics make a valid point when they accuse contemporary "universalist" conceptions of uncritically adopting beliefs, norms, and values predominant in Western culture: their unwillingness to constructively engage in a debate on what would be the most appropriate framework for mindfulness leads to an often wholesale (if tacit) acceptance of individualism, competitiveness, etc. that are typical of contemporary laissez-faire economies. The asymmetry between the narrow (formal) and broad (informal) context is vividly expressed by the following analogy: contemporary meditators, who tend to practice meditation with great devotion, but typically do not abide to ethical principles between meditation retreats, are likened to a "thief who after he gets caught hires a clever lawyer to get him out of trouble," but as soon as he is free he starts stealing again (Ajahn Chah in Amaro 2015, 17). The exclusive focus on formal meditation can make us blind to large-scale (ethical, social, environmental, etc.) issues, and thereby perpetuate injustices inherent in the system whose norms and values we tacitly adopt.

But what would be a more appropriate framework for contemporary approaches? Our previous reflections on the "dark night of the soul" may provide a valuable key. Contemporary accounts that construe mindfulness meditation as a relaxation and/or attention-enhancing technique are bound to interpret the potentially painful and frightening phenomena that may occur in strictly negative terms-as aberrations, side effects, pathological conditions, etc.- - even though classical manuals often depict them as constitutive of meditative practice. Traditional accounts, on the other hand, provide elaborate descriptions and classifications of such phenomena, but are so strongly embedded in their specific (religious, mythical, etc.) discourse that they may seem far removed from concerns of the contemporary reader. In other words, if contemporary approaches lack a comprehensive narrative that would provide a meaningful link between mindfulness and "contemplative suffering", traditional approaches often seem too exotic or far-fetched to be readily integrated into contemporary (psychological, psychotherapeutic, philosophical, etc.) discourse. In the long run, this might have a deleterious effect on the overall attitude towards mindfulness meditation. For example, the rapid 
spread of meditative techniques (without proper guidance, know-how, etc.) and consequent rise in "unwanted side effects" may instigate a shift from the mythization phase, in which mindfulness is presented as a panacea for all the ills and evils of contemporary society, to the demonization phase, in which it will be stigmatized as something too unpredictable and hazardous for clinical purposes. The rise and fall of enthusiasm for the therapeutic use of hallucinogenic drugs in the 1960s and 1970s is a telling (if extreme) example of how easily the pendulum can swing the other way.

It seems to me very unlikely that these potentially deleterious trends could be checked by a wholesale adoption of the classical Buddhist framework, as suggested by the more traditionally-minded critics. Instead, a two-step strategy might prove more efficient. First, it is important to acknowledge and accept the indispensability of broader contextual factors, i.e., the fact that there is no context-free "essence" of mindfulness meditation, and that mindfulness constitutes but one element in the overall philosophical (spiritual, etc.) edifice. Secondly, greater care should be taken in examining and choosing the appropriate frameworks (yes, plural-for why should there be only one legitimate framework?) for contemporary recontextualization of such practices. After all, and as pointed out by Davis, questions about what constitutes "right" (wholesome, etc.) mindfulness should not revolve around doctrinal orthodoxy, but rather around the question of what constitutes a good (wholesome, meaningful) life (Davis 2015, 47). In this sense it may be wise, first and foremost, to consider the possibility not of doctrinal or ethical (at least not in the sense of deontological ethics) (re)contextualization, but instead of existential (re)contextualization: how to meaningfully incorporate mindfulness meditation into the broader search for existential meaning at the beginning of the twenty-first century. One of the central threads in this existential and more mindful (!) (re) framing of mindfulness, a thread closely intertwined with our discussion of the "dark night of the soul", could be a gradual expansion of our current understanding of suffering so as to include not only "standard" mental afflictions (anxiety, depression, etc.; i.e., Pāli $d u k k h a-d u k k h a)$, but also deeper existential concerns-concerns pertaining to the changing, impermanent, and transitory nature of ourselves and the world (i.e., Pāli viparinama-dukkha and sankhara-dukkba), the alleviation of which calls not only for minor epistemological shifts, but for radical ontological transformation. In this respect, whether a certain affliction constitutes a "dark night of the soul" or not would depend on whether it is ultimately constitutive for instantiating this profound transformation of one's manner of being or not.

It is perhaps somewhat unfortunate that mindfulness originally struck roots in the milieu of behavioural and cognitive therapies. For while such therapies prove to be efficient in (at least short-term) reduction of psychological distress, their 
individualistic and biomedical conceptions of human nature generally deprive them of the resources needed to adequately thematize and address deeper existential issues. For this reason, it might be worthwhile to examine possibilities for embedding mindfulness into contexts that show greater sensitivity to existential dimensions, e.g. Frankl's logotherapy, Fromm's humanistic psychoanalysis, and Yalom's and May's existential therapies. What all these approaches have in common is not only a keener appreciation for fundamental existential concerns (dying, suffering, angst, etc.), but also the conviction that these concerns can be appropriately dealt with only by letting go of the atomized, individualistic conceptions of human existence, and by focusing on establishing and maintaining authentic relations with the world and others. This would provide mindfulness-based techniques with a framework that is much closer to the original Buddhist framework of the Four Noble Truths, and would therefore enable practitioners to construe and practice meditation in terms not only of symptom-reduction, but also of profound (and often quite painful) existential transformation on both individual and social levels.

\section{References}

Amaro, Ajahn. 2015. “A Holistic Mindfulness.” Mindfulness 6 (1): 63-73.

Bishop, Scott et al. 2004. "Mindfulness: A Proposed Operational Definition." Clinical Psychology: Science and Practice 11 (3): 230-41.

Black, David S. 2014. "Mindfulness-Based Interventions: An Antidote to Suffering in the Context of Substance Use, Misuse, and Addiction." Substance Use E Misuse 49 (5): 487-91.

Bodhi, Bhikkhu. 2011. "What Does Mindfulness Really Mean? A Canonical Perspective." Contemporary Buddhism 12 (1): 19-39.

Buddhaghosa. 2011. The Path of Purification. Kandy: Buddhist Publication Society. Castillo, Richard J. 1990. "Depersonalization and Meditation." Psychiatry 53 (2): 158-68.

Chadwick, Paul, Katherine Newman Taylor, and Nicola Abba. 2005. "Mindfulness Groups of People with Psychosis." Behavioural and Cognitive Psychotherapy 33 (3): 351-9.

Chiesa, Alberto, and Alessandro Serretti. 2010. "A Systematic Review of Neurobiological and Clinical Features of Mindfulness Meditations." Psychological medicine 40 (8): 1239-52.

Chiesa, Alberto, and Peter Malinowski. 2011. "Mindfulness-Based Approaches: Are They All the Same?" Journal of clinical Psychology 67 (4): 404-24.

Davis, Jake H. 2015. "Facing Up the Question of Ethics in Mindfulness-Based Interventions.” Mindfulness 6 (1): 46-48. 
Dobkin, Patricia L., Julie A. Irving, and Simon Amar. 2011. "For Whom May Participation in a Mindfulness-based Stress Reduction Be Contraindicated?" Mindfulness 3 (1): 44-50.

Dorjee, Dusana. 2010. "Kinds and Dimensions of Mindfulness: Why It Is Important to Distinguish Them." Mindfulness 1 (3): 152-60.

Dreyfus, Georges. 2011. "Is Mindfulness Present-Centred and Non-Judgmental? A Discussion of the Cognitive Dimensions of Mindfulness." Contemporary Buddhism 12 (1): 41-54.

Dunne, John. 2011. “Toward an Understanding of Non-Dual Mindfulness." Contemporary Buddhism 12 (1): 71-88.

—. 2015. "Buddhist Styles of Mindfulness: A Heuristic Approach." In Handbook of Mindfulness and Self-Regulation, edited by Brian D. Ostafin, Michael D. Robinson, and Brian P. Meier, 251-70. New York: Springer.

Edwards, Jesse, et al. 2011. "The Neurobiological Correlates of Meditation and Mindfulness." In Exploring Frontiers of the Mind-Brain Relationship. Mindfulness in Behavioral Health, edited by A. Moreira-Almeida and F. S. Santana Santos, 97-112. New York: Springer.

Epstein, Mark D., and Jonathan D. Lieff. 1981. "Psychiatric Complications of Meditation Practice." The Journal of Transpersonal Psychology 13 (2): 137-47.

Garfield, Jay L. 2015. Engaging Buddhism: Why It Matters to Philosophy. Oxford: Oxford University Press.

Gethin, Rupert. 1992. The Buddhist Path to Awakening. Leiden and New York: Brill's Indological Library.

—. 2011 "On Some Definitions of Mindfulness." Contemporary Buddhism 12 (1): 263-79.

Grossman, Paul, et al. 2004. "Mindfulness-based Stress Reduction and Health Benefits: A Meta-Analysis." Journal of Psychosomatic Research 57: 35-43.

Hakuin. 2010. Wild Ivy: The Spiritual Autobiography of Zen Master Hakuin. Boston and London: Shambala.

Harrington, Anne and John Dunne. forthcoming. "Mindfulness Meditation: Frames and Choices," American Psychologist 1-27. Accessed October 15, 2015. https://dash.harvard.edu/bitstream/handle/1/10718406/46521719. pdf? sequence $=1$.

Healey, Kevin. 2013. "Searching for Integrity: The Politics of Mindfulness in the Digital Economy." Nomos Journal. Accessed March 6, 2016. http://nomosjournal.org/2013/08/searching-for-integrity/.

Hickey, Wakoh Shannon. 2010. "Meditation as Medicine: A Critique." Cross Currents 60 (2): 168-84.

John of the Cross. 1946. Ascent of Mount Carmel. Westminister: Newman Bookshop. 
Kabat-Zinn, Jon. 1994. Wherever You Go, There You Are: Mindfulness Meditation for Everyday Life. New York: Hyperion.

—. 2011. "Some Reflections on the Origins of MBSR, Skillful Means, and the Trouble with Maps." Contemporary Buddhism 12 (1): 281-306.

Kerr, Catherine. 2014. "Why Do Studies of Meditation and of the Brain Matter?" Huffington Post. Accessed February 28, 2016. http://www.huffingtonpost. $\mathrm{com} /$ catherine-kerr/why-do-studies-of-meditat_b_6075664.html.

Kirmayer, Laurence J. 2015. "Mindfulness in Cultural Context." Transcultural Psychiatry 52 (4): 447-69.

Kordeš, Urban, and Olga Markič. forthcoming. "Parallels between Mindfulness and First-person Research of Consciousness." Asian Studies 4 (2).

Kuijpers, Harold J. H., et al. 2007. "Meditation-induced Psychosis.” Psychopathology 40: 451-64.

Lopez, Jr., Donald S. 2002. A Modern Buddhist Bible. Readings for the Unenlightened. London: Penguin Books.

Lustyk, M. Kathleen B., et al. 2009. "Mindfulness Meditation Research: Issues of Participant Screening, Safety Procedures, and Research Training." Advances in Mind-Body Medicine 24 (1): 20-30.

Mackenzie, Vicki. 2001. Why Buddhism?: Westerners in Search of Wisdom. Crows Nest, N.S.W: Allen \& Unwin.

Manocha, Ramesh. 2000. "Why Meditation?" Australian Family Physician 29: 1135-38.

McCown, Donald. 2013. The Ethical Space of Mindfulness in Clinical Practice: An Exploratory Essay. Philadelphia: Jessica Kingsley.

McMahan, David L. 2008. The Making of Buddhist Modernism. Oxford: Oxford University Press.

Michal, Matthias, et al. 2007. "Depersonalization, Mindfulness, and Childhood Trauma.” Journal of Nervous Mental E' Mental Disease 40 (4): 285-94.

Mikulas, William L. 2015. "Ethics in Buddhist Training." Mindfulness 6 (1): 14-16. Monteiro, Lynette M., R. F. Musten, and Jane Compson. 2015. "Traditional and Contemporary Mindfulness: Finding the Middle Path in the Tangle of Concerns." Mindfulness 6 (1): 55-70.

Nyanaponika, Thera. 1973. The Heart of Buddhist Meditation: A Handbook of Mental Training Based on the Buddha's Way of Mindfulness. New York: Samuel Weiser.

Olendzki, Andrew. 2011. “The Construction of Mindfulness." Contemporary Buddhism 12 (1): 55-70.

Purser, Ronald E., and David Loy. 2013. "Beyond McMindfulness.” Huffington Post. Accesssed February 28, 2016. http://www.huffingtonpost.com/ ron-purser/beyond-mcmindfulness_b_3519289.html. 
Purser, Ronald E. 2014. “The Militarization of Mindfulness.” Inquiring Mind. Accessed February 28, 2016. http://www.inquiringmind.com/Articles/MilitarizationOfMindfulness.html.

- 2015a. "Clearing the Muddled Path of Traditional and Contemporary Mindfulness: A Response to Monteiro, Musten, and Compson." Mindfulness 6 (1): 23-45. —. 2015b. "The Myth of the Present Moment." Mindfulness 6 (3): 680-6.

Ricard, Matthieu. 2009. “A Sniper's Mindfulness.” Accessed January 14, 2016. http://www.matthieuricard.org/en/blog/posts/a-sniper-s-mindfulness.

Rocha, Thomas. 2014. "The Dark Night of the Soul." The Atlantic. Accessed January 14, 2016. http://www.theatlantic.com/health/archive/2014/06/ the-dark-knight-of-the-souls/372766/).

Sauser, Sebastian, and Niko Kohls. 2010. "Mindfulness in Leadership: Does Being Mindful Enhance Leaders' Business Success?” In Culture and Neural Frames of Cognition and Communication, edited by Shihuhi Han and Ernst Pöpper, 287-307. New York: Springer.

Sayādaw, Mahāsī. 1971. Practical Insight Meditation: Basic and Progressive Stages. Kandy: Buddhist Publications Society.

—. 1995. The Progress of Insight. Kandy, Sri Lanka: Buddhist Publications Society. Accessed January 14, 2016. http://enlight.lib.ntu.edu.tw/FULLTEXT/ JR-AN/an141147.pdf.

Sedlmeier, Peter, et al. 2012. "The Psychological Effects of Meditation: A Meta-Analysis." Psychological Bulletin 138 (6): 1139-71.

Segall, Seth Zuiho. 2013. "In Defense of Mindfulness." Existential Buddhist. Accessed January 14, 2016. http://www.existentialbuddhist.com/2013/12/ in-defense-of-mindfulness/.

Shapiro, Deane H., Jr. 1992. "Adverse Effects of Meditation: A Preliminary Investigation of Long-Term Investigators." International Journal of Psychosomatics 39: 62-67.

Sharf, Robert H. 1993. "The Zen of Japanese Nationalism.” History of Religions 33 (1): 1-43.

—. 1995. "Buddhist Modernism and the Rhetoric of Meditative Experience." Numen 42: 228-83.

—. 2014a. "Is Mindfulness Buddhist? And Why It Matters." Transcultural Psychiatry 1-12.

—. 2014b. "Mindfulness and Mindlessness in Early Chan." Philosophy East Eซ West 64 (4): 933-64.

Siderits, Mark. 2007. Buddhism as Philosophy: An Introduction. Aldershot: Ashgate. Stanley, Elisabeth A., and Amishi Jha. 2009. "Mind Fitness: Improving Operational Effectiveness and Building Warrior Resilience." Joint Force Quarterly 55: 144-51. 
Stanley, Steven. 2015. "Sìla and Sati: An Exploration of Ethics and Mindfulness in Pāli Buddhism and Their Implications for Secular Mindfulness-Based Applications." In Buddhist Foundations of Mindfulness, edited by Edo Shonin, William Van Gordon, and Nirbhay N. Sing, 89-113. New York: Springer.

Tang, Yi-Yuan, Britta K. Hölzel, and Michael Posner. 2015. "The Neuroscience of Mindfulness Meditation." Nature Reviews Neuroscience 16: 213-25.

The Cloud of Unknowing. 1922. London: John M. Watkins.

Thompson, Evan. 2007. "Neurophenomenology and Contemplative Experience." In The Oxford Handbook of Science and Religion, edited by Philip Clayton, 22635. New York: Oxford University Press.

Van Gordon, William, et al. 2015. "There is Only One Mindfulness: Why Science and Buddhism Need to Work Together." Mindfulness 6 (1): 49-56.

Victoria, Brian. 2006. Zen at War. Oxford: Rowman \& Littlefield.

Vörös, Sebastjan. 2015. "Sedenje z demoni: čuječnost kot eksistencialno-transformativna praksa." Poligrafi 77/78: 139-69.

—. 2016. "Buddhism and Cognitive (Neuro)Science: An Uneasy Liaison." Asian Studies 4 (1): 61-80.

—. 2016. Forthcoming. "Mindfulness De- or Recontextualized? Traditional Buddhist and Contemporary Perspectives." Taiwan Journal of East Asian Studies 13 (1): 1-34

Wallace, Alan B. 2012. Meditations of a Buddhist Sceptic: A Manifesto for the Mind Sciences and Contemplative Practices. New York: Columbia University Press.

Wilson, Jeff. 2014. Mindful America: The Mutual Transformation of Buddhist Meditation and American culture. Oxford: Oxford University Press. 